\title{
Comparing the Bacteriological and Physicochemical Properties of House-hold Drinking Water in Uli and Assessing the Associated Public Health Implications
}

\author{
Umeaku Chinyelu Nkiru ${ }^{1}$, Chris-Umeaku Chiamaka Ijeoma ${ }^{2}$, Okeke Ugocukwu Chibeze ${ }^{1}$, \\ Uzor Chiagoziem Ugonwa ${ }^{3}$, Samuel Adaora Kosisochukwu ${ }^{1}$ \\ ${ }^{1}$ Department of Microbiology, Chukwuemeka Odumegwu Ojukwu University, Uli Campus, Uli, Nigeria \\ ${ }^{2}$ Department of Biochemistry, Chukwuemeka Odumegwu Ojukwu University, Uli Campus, Uli, Nigeria \\ ${ }^{3}$ Department of Mass Communicatiotion, Chukwuemeka Odumegwu Ojukwu University, Igbariam Campus, Igbariam, Nigeria
}

Email address:

chimeaku@yahoo.com (U. C. Nkiru)

\section{To cite this article:}

Umeaku Chinyelu Nkiru, Chris-Umeaku Chiamaka Ijeoma, Okeke Ugocukwu Chibeze, Uzor Chiagoziem Ugonwa, Samuel Adaora Kosisochukwu. Comparing the Bacteriological and Physicochemical Properties of House-hold Drinking Water in Uli and Assessing the Associated Public Health Implications. International Journal of Environmental Chemistry. Vol. 4, No. 2, 2020, pp. 46-53. doi: $10.11648 /$ j.ijec.20200402.12

Received: July 15, 2019; Accepted: October 4, 2019; Published: October 13, 2020

\begin{abstract}
A study of the comparative analysis of house-hold drinking water quality in Uli, Anambra State was carried out in the Microbiology Laboratory of Chukwuemeka Odumegwu Ojukwu University, Uli to evaluate the water, with a view to assessing the public health implication of water from these sources. Trips were made to living homes to obtain samples of their drinking water. Twenty Samples were used for the study. Ten samples were collected from homes that drank straight from the boreholes. Five samples were collected from those that drank sachet water and five from those that drank bottled water. Microbiological and physicochemical parameters were utilized using standard methods. Most probable number (MPN) technique was employed in the bacteriological analysis of the water samples. Biochemical tests were utilized in the identification of the microorganisms. Results based on the cultural, morphological and biochemical characteristics, revealed the samples to contain three isolates identified as Escherichiacoli, Staphylococcus aureus and Klebsiella sp. The pH of all the treated water samples were neutral, pH of the borehole water samples was neutral. The temperature of the sachet water samples ranged between $22.5-23.5$ whereas that the borehole water samples were $22^{\circ} \mathrm{C}-22.2^{\circ} \mathrm{C}$ respectively. The total dissolved solid of the treated water samples ranged between $0.82 \mathrm{mg} / 1$ and $1.60 \mathrm{mg} / 1$, whereas that of the borehole water samples ranged between $7.07-20 \mathrm{mg} / \mathrm{l}$. The total suspended solids of the treated water samples were not detected whereas that of the borehole water samples ranged between $31-55 \mathrm{mg} / \mathrm{l}$. Results from total coliform counts for the samples were highest in the boreholes with a total coliform count of 2.4MPN per ml. Faecal coliform count was highest in the borehole samples. The presence of high faecal coliform count in the borehole samples could be attributed to the proximity of the boreholes to pit latrines at distances less than the $30 \mathrm{~m}$. This does not conform with WHO recommendations for safe drinking water. From the results, all the untreated drinking water sampled from Uli were unfit for human consumption. This could be responsible for the incessant gastroenteritis, staphylococcal toxic shock syndrome, dysentery and Klebsiella pneumonia observed in Uli and environs. This study suggests that all the drinking water from various sources used by the inhabitants of Uli and environs should be treated before drinking.
\end{abstract}

Keywords: Water, MPN, Faecal, Coliform, Drinking

\section{Introduction}

Water is an essential requirement for human and industrial development which is used directly or indirectly in many processes in large quantities, as a neutral compound containing hydrogen and oxygen with a variety of dissolved and suspended solids [4]. A reliable supply of clean wholesome water is highly essential in a bid to promoting healthy living amongst the inhabitants of any defined region [10]. Therefore, accessibility and availability of fresh clean water is a key to 
sustainable development and essential element of health, food production and poverty reduction [8].

An essential 2.1 billion people around the world lack access to safe water and close to 2.5 billion are not provided with adequate sanitation [5]. Water is classified as natural or artificial depending on the various sources. Major sources of water include; springs, ponds, streams, rivers, oceans, rain and underground water [9]. The variety of water sources bring in many impurities in water as recent findings have it that drinking water can be made artificial through sewage recycling process [11]. Drinking water can be supplied as tap, sachet, bottle etc., which must be safe for human consumption [7], irrespective of the form of supply, drinking water has to meet certain standards before human consumption. These requirements make up what is referred to as the quality of drinking water. Failure of drinking water to meet these standards may have harmful effects on humans, which could be of social and economic importance to human populace [1].

Microbiologically, drinking water quality is measured using indictor organisms whose presence in an environment indicates the presence of other contaminating substances which pose a risk to human health [3]. It therefore becomes important that bacteriological quality of drinking water packaged in sachets and bottles, and distributed to consumers in Uli, Anambra State be evaluated using these indicators as many microbial diseases in developing countries like Nigeria have been implicated from the consumption of these sachet and bottled water.

\subsection{Statement of Problem/Justification}

In Uli, Nigeria, rivers used to be the main source of drinking water. With the recent development, the sinking of boreholes has come to stay since most of these rivers are far from living homes. Boreholes are sunk in the living areas of the populace and has now become more convenient.

Due to poverty, most families cannot afford bottled water for their drinking water purposes, only few afford sachet water. The majority of the inhabitants drink water straight from boreholes. According to WHO standards and guidelines, boreholes should be sunk $150 \mathrm{ft}$ below the ground level, new septic tanks or human waste lagoons be installed at least $50 \mathrm{ft}$ from a well and that septic tank drain fields must be at least $100 \mathrm{ft}$ from a well. Boreholes and wells should be situated far and opposite from refuse disposal and sewage disposal sites, but in Uli some of these standards are not met.

This inability to meet up with standards brings with it, multiplicity of waterborne diseases. There is urgent need to microbiologically, chemically and physico-chemically evaluate the quality of water fed to the populace in Uli with a view to assessing the portability of the water. It is necessary to recommend ways of treating the water fed to the community, and forwarding such recommendation to relevant authorities, as well as storing the information so obtained in easily retrievable database for use by all.

\section{2. $\operatorname{Aim}$}

This research was undertaken to ascertain the portability of water drank in different living homes in Uli, Anambra State using physico-chemical and microbiological methods with a view to assessing the public health problems associated with drinking water from these sources.

\subsection{Objectives of the Study}

1. To collect drinking water samples from 20 different homes in Uli.

2. To carry out bacteriological analysis on the water samples.

3. To carry out physico-chemical analysis on these water samples.

4. To biochemically identify the microbial isolates.

5. To check if the results obtained from the analysis comply with WHO standards for drinking water.

6. To develop methods of communicating result to relevant authorities.

7. To give advice to the general public based on the results of the research.

\section{Materials and Methods}

\subsection{Collection of Water Samples}

Visits were made to twenty (20) students lodges to obtain samples of their drinking water. Water samples were collected from students lodges using clean plastic cans, labeled and transported immediately to the Laboratory in ice pack for physicochemical analysis. For bacteriological analysis, aliquot of concentrated ethanol were added to the sample bottles and washed out as means of sterilization. The cans were rinsed severally. The taps were disinfected by cleaning with ethanol swabs, opened fully and water was allowed to run off for two minutes before collection. The samples were labeled and transported to the Laboratory in ice Pack. Table 1 below shows the randomly selected sample locations, sources and sample identification codes.

Table 1. Sample locations, sources and identification codes.

\begin{tabular}{|c|c|c|}
\hline Sample No & Source of Supply & Sample Identification code \\
\hline 1 & \multirow{9}{*}{ Borehole } & $\mathrm{S} 1$ \\
\hline 2 & & $\mathrm{~S} 2$ \\
\hline 3 & & S3 \\
\hline 4 & & S4 \\
\hline 5 & & S5 \\
\hline 6 & & S6 \\
\hline 7 & & S7 \\
\hline 8 & & S8 \\
\hline 9 & & S9 \\
\hline 10 & \multirow{6}{*}{ Sachet water } & S10 \\
\hline 11 & & S11 \\
\hline 12 & & S12 \\
\hline 13 & & S13 \\
\hline 14 & & S14 \\
\hline 15 & & S15 \\
\hline 16 & \multirow{5}{*}{ Bottled water } & S16 \\
\hline 17 & & S17 \\
\hline 18 & & S18 \\
\hline 19 & & S19 \\
\hline 20 & & $\mathrm{~S} 20$ \\
\hline
\end{tabular}




\subsubsection{Equipment}

The following equipment were used for this study; autoclave, incubator, analytical machine, digital microscope, spectrophotometer, shaker bath, electrical generating set, electric top-loading weighing balance, gas cylinder, colony counter, refrigerator, evaporating dish, oven.

\subsubsection{Media and Reagents}

The Laboratory media and reagents used for this study include; MacConkey broth, brilliant green lactose bile broth, eosine methylene blue agar, nutrient agar, Simmon citrate agar, Kovac reagent, methyl red indicator, peptone water, glucose phosphate broth, 5\% alcoholic alpha-naphthol, 40\% $\mathrm{KOH}$ solution, Grams reagent, nutrient broth, Lauryl tryptone broth, EC broth, bromocrysol purple, LES endo agar, EC mug broth, hydrogen peroxide.

\subsubsection{Materials}

Other materials used for this research are sterile cotton wool, conical flasks, aluminum foil, disposable Petri dishes, Bunsen burners, ethanol, spatulas, Whatman number 1 filter papers, pipette fillers, slides and cover slips, test tubes, Durham tubes, masking tape, measuring cylinders, syringe and needles, beakers, test tube racks, thermometer, desiccator, pipettes, standard buffers, inoculation loops.

\subsubsection{Sterilization of Glassware}

All glassware used for this study were sterilized using the electric laboratory oven set at $160^{\circ} \mathrm{C}$ for one hour.

\subsection{Physiochemical Analysis}

The samples were analyzed for $\mathrm{pH}$, total dissolved solids, total suspended solids and temperature.

\subsubsection{Determination of $\mathrm{pH}$}

The $\mathrm{pH}$ of the water samples was determined using the Hanna microprocessor $\mathrm{pH}$ meter. It was standardized with a buffer solution in accordance with the modified methods of [10] with a $\mathrm{pH}$ range between 4-9.

\subsubsection{Measurement of Temperature}

This was carried out in-situ at the site of sample collection using a mobile thermometer. This was done by dipping the thermometer into the sample and recording the stable reading.

\subsubsection{Determination of Total Solids (TS) by Gravimetric Method}

Ten (10) $\mathrm{ml}$ of the samples were measured into a preweighed evaporating dish which was then dried in an oven at a temperature of 103 to $105^{\circ} \mathrm{C} \mathrm{S} 2$ (Sample 2) for two and half hours. The dish was transferred into a desiccators and allowed to cool to room temperature and was weighed using modified methods of [6]. The total solid was represented by the increase in weigh of the evaporating dish.

$$
\text { Total solids }(\mathrm{mg} / 1)=[\mathrm{W} 2-\mathrm{W} 1) \mathrm{mg} \times 1000] / \mathrm{ml} \text { of sample }
$$

Where W1=initial weight of evaporating dish
W2=Final weight of the dish (evaporating dish + residue)

\subsubsection{Determination of Total Dissolved Solids (TDS) by Gravimetric Method}

A portion of water was filtered out and $10 \mathrm{ml}$ of the filtrate was measured into a pre-weighed evaporating dish. Following the procedure for the determination of total solids above, the total dissolved solids content of the water was calculated.

Total dissolved solids $(\mathrm{mg} / \mathrm{l})=[\mathrm{W} 2-\mathrm{W} 1 \mathrm{mg} \times 100] / \mathrm{ml}$ of filtrate used.

Where w1=initial weight of evaporating dish W2=Final weight of the dish (evaporating dish + residue).

\subsubsection{Determination of Total Suspended Solids (TSS)}

The total suspended solids were easily obtained by simple calculation, i.e.

Total suspended solids=total solid-total dissolved solids.

\subsection{Bacteriological Quality Determination}

Total coliform and total faecal coliform were determine using most probable number (MPN) of coliform techniques as described below using modified methods of [7].

\subsubsection{Presumptive Test}

Coliform counts were obtained using the three-tube assay of the Most Probable Number (MPN) technique [7]. Presumptive coliform test was performed using MacConkey broth (Oxoid). The first set of three tube shad sterile $10 \mathrm{ml}$ double strength broth and the second and third sets had $10 \mathrm{ml}$ single strength broth. All the tubes contained Durham tubes before sterilization. The three sets of tubes received $10 \mathrm{ml}$, $1 \mathrm{ml}$ and $0.1 \mathrm{ml}$ quantities of water samples respectively using sterile pipettes and pipette fillers. The tubes were incubated at $37^{\circ} \mathrm{C}$ for $24-48 \mathrm{~h}$ for estimation of total coliforms and at $44.5^{\circ} \mathrm{C}$ for faecal coliforms for $24-48 \mathrm{~h}$ and examined for acid and gas production. Acid production was determined by colour change of the broth from reddish purple to yellow and gas production was checked for by entrapment of gas in the Durham tube.

The MPN was then estimated from the MPN table for three tube test.

\subsubsection{Confirmed Test}

Confirmed test was carried out by transferring a loop-full of culture from a positive tube from the presumptive test into a tube of Brilliant Green Lactose Bile (BGLB) broth (Oxoid) with Durham tubes. The tubes were incubated at $37^{\circ} \mathrm{C}$ for $24-$ $48 \mathrm{~h}$ for total coliforms and $44.5^{\circ} \mathrm{C}$ for faecal coliforms and observed for gas production [7].

\subsubsection{Completed Test}

Faecal coliform count was determined using pour plate technique. Eosin methylene blue agar was used. Organisms with greenish metallic sheen were taken as positive for $E$. coli. This was further confirmed by the ability of the organism to ferment lactose at $44.5^{\circ} \mathrm{C}$. Colonies developing 
on EMB agar, were further identified as coliforms or faecal coliforms (Escherichia coli) using cultural characteristics, morphology and biochemical tests. For faecal coliforms, colonies with green metallic sheen were Gram stained and the IMVIC test was carried out on nutrient agar stock cultures and used to identify the colony as E.coli. The MPN per $100 \mathrm{ml}$ water was calculated using the completed test table.

\subsection{Identification of Bacterial Isolates}

Stock cultures of the isolates with different cultural characteristics were made on nutrient agar slants. Gram staining was used to check for morphology and biochemical tests were performed to aid in identification. Various tests were performed and used in probable identification of isolates, they include; the oxidase test, motility test, catalase test, urease test, coagulase test, indole test, methyl red test, Voges-Proskauer test and citrate utilization [2].

\subsubsection{Biochemical Test}

These tests are used for further characterization and identification of bacterial isolates.

(i). Citrate Test

As described by [12], this test determines the ability of the organism of grow and utilize citrate as sole carbon source. The medium used was Simmon's citrate agar. It was prepared by dissolving $16.5 \mathrm{~g}$ of Simmon's citrate in $300 \mathrm{ml}$ of deionized water. The medium was then dispensed in $10 \mathrm{ml}$ amount into screw-capped bottles and sterilized. The medium was allowed to set in a slanting position. Portions of pure culture were now inoculated into the medium by stabbing and streaking onto the slants. The cultures were then incubated for 2 days and observed daily for change in colour of the medium from green to blue, which indicates a positive result.

(ii). Indole Test

As stated by [12], indole is a nitrogen-containing compound formed when the amino acid, tryptophan is hydrolyzed by bacteria that have the enzyme tryptophanase. This is detected by using kovac's reagent. For this test, isolates were grown in peptone water in $500 \mathrm{ml}$ of deionized water. The medium was dispensed into test tubes in $10 \mathrm{ml}$ amounts and sterilized. This was then inoculated with the isolates and then incubated at $37^{\circ} \mathrm{C}$ for 24 hours. Five drops of kovac's reagent were carefully layered onto the top of the 24 hours old culture. The presence of indole was revealed by the formation of red layer coloration on top of the broth culture.

\section{(iii). Methyl Red Test}

This test determines the fermentation capacity of a given bacterial culture. Glucose phosphate broth was prepared and distributed in test tubes these test tubes were further sterilized by autoclaving. The sterile test tubes were inoculated with test culture and incubated at $37^{\circ} \mathrm{C}$ for 24 hours. After incubation 5 drops of methyl-red indicator was added to the medium and the tubes were observed for development of red colour.

\section{(iv). Voges-proskauer (V-P) Test}

This test demonstrates the capacity of bacterial culture to carry out fermentation. Glucose phosphate broth was prepared and distributed in test tubes, these test tubes and content were further sterilized by autoclaving. The sterile broth were inoculated with test culture and incubated at $37^{\circ} \mathrm{C}$ for 24 hours. After incubation $0.6 \mathrm{ml}$ of alpha naphthol and $0.2 \mathrm{ml}$ of $\mathrm{KOH}$ solution per $\mathrm{ml}$ of culture broth media were added. Further, after the addition of these two reagents the culture tubes were shaken properly and kept in slanting position to increase aeration. This position was maintained for about one hour and then results were noted down. Thus formation of pink color indicates presence of acetoin and confirms butanediol fermentation and indicates V-P test as positive.

(v). Catalase Test

As stated by [12], hydrogen peroxide was the reagent used. A loop-full of the bacteria from a 24 hour-old pure culture was transferred to clean glass slide and a drop of hydrogen peroxide was added to the bacteria on the slide. Effervescence caused by the liberation of free oxygen as gas bubbles revealed a positive result indicating the presence of catalase in the culture. Catalase is an enzyme capable of decomposing hydrogen peroxide to water and oxygen.

(vi). Oxidase Test

This was carried out using the modified methods of [12]. Oxidase reagent containing $1 \%(\mathrm{w} / \mathrm{v})$ tetramethyl-p-phenyl dihydrochloride was prepared by dissolving $0.1 \mathrm{~g}$ of this compound in $10 \mathrm{ml}$ of deionized water. Strip of filter paper was soaked with this reagent, smears of the isolate from the pure cultures were made on the oxidase paper strips and observed for colour change from grey to purple or violet color between one to five seconds for oxidase positive organisms. For oxidase negative organisms, there is no color change. The change in colour is due to the presence of cytochrome.

(vii). Coagulase Test

This method was used to identify Staphylococcus aureus. A drop physiological saline was dropped on the slide. A colony of the test organism that has stayed for $24 \mathrm{hrs}$ was emulsified in each of the drops to make a thick suspension, a drop of plasma was added to one of the suspensions and was mixed gently. Clumping indicated positive result while no clumping indicated negative result.

\subsubsection{Gram Staining}

Selected colony was stained by Gram method [12]. A drop of sterile water was used to clean the slide. A thin film of bacterial colony was placed into the drop of water on the slide, emulsified with the aid of sterile wire loop. The smear was allowed to air dry, and then passed through flame to heat fix. After cooling, the smear was flooded with crystal violet stain for $60 \mathrm{sec}$. After which, it was rinsed in running tap water. The film was then covered with Lugol's iodine and allowed to stay for $60 \mathrm{sec}$ and then rinsed with water, 3 drop of $70 \%$ ethanol was used to decolorized it for $10 \mathrm{sec}$ and rinsed thoroughly with water. Safranin solution was used to 
stain for $60 \mathrm{sec}$ and then rinsed lightly with water. The slide was allowed to air dry and examined with low power objectives and finally under the oil immersion objective. There were red/pink or purple background indicating Gramnegative or Gram-positive bacteria.

\section{Results}

Table 2 shows the physicochemical characteristics of the borehole and sachet water samples. The result of physicochemical analysis of borehole and sachet water samples revealed that the $\mathrm{pH}$ of the all the treated water samples; S6, S7, S8, S9 and S10 were 7.00, 7.01, 7.02, 6.98 and 7.01 respectively whereas that of the borehole water samples S1, S2, S3, S4 and S5 were 7.01, 6.99, 7.01, 7.01 and 6.99 respectively. The temperature of the sachet water samples S6, S7, S8, S9 and were $23^{\circ} \mathrm{C}, 22.5^{\circ} \mathrm{C}, 22.5^{\circ} \mathrm{C}$, $23.4^{\circ} \mathrm{C}$ and $22.5^{\circ} \mathrm{C}$ respectively whereas that the borehole water samples, S1, S2, S3, S4, S5 were $22^{\circ} \mathrm{C}, 22^{\circ} \mathrm{C}, 22^{\circ} \mathrm{C}$, $22.1^{\circ} \mathrm{C}$ and $22.2^{\circ} \mathrm{C}$ respectively. The total dissolved solid of the treated water samples S6, S7, S8, S9 and S10 were $1.60 \mathrm{mg} / 1, \quad 0.82 \mathrm{mg} / 1, \quad 0.32 \mathrm{mg} / 1, \quad 0.21 \mathrm{mg} / 1$ and $0.8 \mathrm{mg} / 1$ respectively whereas that of the borehole water samples were $20.7 \mathrm{mg} / 1, \quad 11.0 \mathrm{mg} / \mathrm{l}, \quad 7.07 \mathrm{mg} / 1 \quad 20.6 \mathrm{mg} /$ and $17 \mathrm{mg} / \mathrm{l}$ respectively. The total suspended solids of the treated water samples S6, S7, S8, S9 and S10 were not detected whereas that of the borehole water samples were $35.4 \mathrm{mg} / 1,31.3 \mathrm{mg} / \mathrm{l}$, $36.8 \mathrm{mg} / 1,55.0 \mathrm{mg} / 1$ and $35.3 \mathrm{mg} / 1$ respectively.

Table 3 shows the values for total coliform counts and faecal coliform counts of water samples. Total coliform counts for the samples were also highest sample S1, with total coliform count of 2.4 MPN per ml while sample S2, S3, S4 S5, S6, S7 S8, S9 and S10 had counts of 1.1, 0.003, 0.043,
0.903, 0.003, 0.003, 0.003 and 0.003 MPN per mililitre respectively.

Faecal coliform count was highest for S4 with value of 2.4 MPN per 100ml. Sample S1, S2, S3, S5, S6, S7, S8, S9 and $\mathrm{S} 10$ had values of $8,6,4,6,4,5,0,0,0$ and 0 respectively.

Based on the cultural characteristics, morphology and results of biochemical tests, three isolates were identified as Escherichia coli, Staphylococcus aureus and Klebsiella sp. As shown in Table 5.

Table 2. Physicochemical parameters of borehole, sachet and bottled water samples.

\begin{tabular}{lllll}
\hline Sample & Ph & Temp. $\left({ }^{\circ} \mathbf{C}\right)$ & TSS (mg/l) & TDS (mg/l) \\
\hline 1 & 7.01 & 22 & 35.4 & 20.7 \\
2 & 6.99 & 22 & 31.3 & 11.0 \\
3 & 7.01 & 22 & 36.8 & 7.07 \\
4 & 7.01 & 22.1 & 55.0 & 20.6 \\
5 & 6.99 & 22.2 & 35.3 & 17.8 \\
6 & 7.00 & 23 & 35.0 & 20.0 \\
7 & 7.01 & 22.5 & 36.8 & 15.5 \\
8 & 7.02 & 22.5 & 40.0 & 17.4 \\
9 & 6.98 & 23.4 & 45.5 & 20.0 \\
10 & 7.01 & 22.5 & 47.5 & 17.2 \\
11 & 7.00 & 23.0 & ND & 1.60 \\
12 & 7.00 & 22.0 & ND & 1.50 \\
13 & 6.99 & 23.0 & ND & 1.50 \\
14 & 7.01 & 24.0 & ND & 1.00 \\
15 & 7.02 & 24.0 & ND & 0.80 \\
16 & 7.00 & 24.0 & ND & 0.32 \\
17 & 7.00 & 24.0 & ND & 0.21 \\
18 & 7.00 & 22.0 & ND & 0.32 \\
19 & 7.00 & 23.0 & ND & 0.50 \\
\hline
\end{tabular}

Table 3. Total coliform

\begin{tabular}{llll}
\hline Water sample & $\begin{array}{l}\text { Number of positive Tubes in 10ml Double } \\
\text { strength Mac Conkey broth }\end{array}$ & $\begin{array}{l}\text { Number of positive Tubes in 9.9ml Single } \\
\text { strength MacConkey broth }\end{array}$ & $\begin{array}{l}\text { Number of positive Tubes in 9ml } \\
\text { Single Strength Mac Conkey Broth }\end{array}$ \\
\hline S1 & 3 & 3 & 3 \\
S2 & 3 & 3 & 2 \\
S3 & 0 & 0 & 0 \\
S4 & 3 & 1 & 0 \\
S5 & 3 & 2 & 0 \\
S6 & 3 & 3 & 3 \\
S7 & 3 & 3 & 2 \\
S8 & 3 & 2 & 0 \\
S9 & 3 & 3 & 2 \\
S10 & 3 & 3 & 3 \\
S11 & 0 & 0 & 0 \\
S12 & 0 & 0 & 0 \\
S13 & 0 & 0 & 0 \\
S14 & 0 & 0 & 0 \\
S15 & 0 & 0 & 0 \\
S16 & 0 & 0 & 0 \\
S17 & 0 & 0 & 0 \\
S18 & 0 & 0 & 0 \\
S19 & 0 & 0 & 0 \\
S20 & 0 & 0 & 0 \\
\hline
\end{tabular}


Table 4. Bacteriological counts of the water samples

\begin{tabular}{lll}
\hline Samples & Total coliform count (MPN/ml) & Faecal coliform count (cfu/ml) \\
\hline S1 & 2.4 & 80 \\
S2 & 1.1 & 60 \\
S3 & 0.003 & 48 \\
S4 & 0.043 & 64 \\
S5 & 0.093 & 50 \\
S6 & 2.4 & 80 \\
S7 & 1.1 & 60 \\
S8 & 0.093 & 50 \\
S9 & 1.1 & 60 \\
S10 & 2.4 & 80 \\
S11 & 0.003 & 0 \\
S12 & 0.003 & 0 \\
S13 & 0.003 & 0 \\
S14 & 0.003 & 0 \\
S15 & 0.003 & 0 \\
S16 & 0.003 & 0 \\
S17 & 0.003 & 0 \\
S18 & 0.003 & 0 \\
S19 & 0.003 & 0 \\
S20 & 0.003 & 0 \\
\hline
\end{tabular}

Table 5. Occurrence of Bacterial species in the water sample

\begin{tabular}{llll}
\hline Water sample & Klebsiella sp. & Staphylococcus sp. & Escherichia coli \\
\hline S1 & - & + & - \\
S2 & + & - & + \\
S3 & - & - & + \\
S4 & - & - & + \\
S5 & + & + & - \\
S6 & + & + & - \\
S7 & + & + & - \\
S8 & - & - & + \\
S9 & + & + & + \\
S10 & + & + & + \\
S11 & - & - & + \\
S12 & - & - & - \\
S13 & - & - & + \\
S14 & - & - & - \\
S15 & - & - & - \\
S16 & - & - & - \\
S17 & - & - & - \\
S18 & - & - & - \\
S19 & - & - & - \\
S20 & - & - & - \\
\hline
\end{tabular}

Table 6. Occurrence of the isolated organisms in the water samples.

\begin{tabular}{|c|c|c|}
\hline Isolated organism & Frequency of occurrence & $\%$ Frequency of occurrence \\
\hline Escherichia coli & 6 & 30 \\
\hline Staphylococcus aureus & 6 & 30 \\
\hline Klebsiella sp. & 6 & 30 \\
\hline Total & 18 & 90 \\
\hline
\end{tabular}

Table 7. Biochemical characterization of the isolates

\begin{tabular}{|c|c|c|c|c|c|c|c|c|c|c|}
\hline Isolates & Morphology & $\begin{array}{l}\text { Gram } \\
\text { stain }\end{array}$ & $\begin{array}{l}\text { Catalase } \\
\text { test }\end{array}$ & Indole test & $\begin{array}{l}\text { Oxidase } \\
\text { test }\end{array}$ & $\begin{array}{l}\text { Methyl } \\
\text { red test }\end{array}$ & $\begin{array}{l}\text { Voges } \\
\text { proskauer }\end{array}$ & $\begin{array}{l}\text { Citrate } \\
\text { test }\end{array}$ & $\begin{array}{l}\text { Coagulase } \\
\text { test }\end{array}$ & Probable organism \\
\hline $\mathrm{A}$ & Rods & -ve & $+\mathrm{ve}$ & $+\mathrm{ve}$ & -ve & $+\mathrm{ve}$ & -ve & -ve & -ve & Escherichia coli \\
\hline B & Rods & -ve & $+\mathrm{ve}$ & -ve & -ve & -ve & $+\mathrm{ve}$ & $+\mathrm{ve}$ & -ve & Klebsiela sp. \\
\hline $\mathrm{C}$ & Cocci & $+\mathrm{ve}$ & $+\mathrm{ve}$ & -ve & -ve & $+\mathrm{ve}$ & -ve & -ve & $+\mathrm{ve}$ & Staphylococcus aureus \\
\hline
\end{tabular}




\section{Discussion}

The $\mathrm{pH}$ of the borehole, sachet and bottle water samples fell within the range of 6.98-7.01 (Table 2) which is normal in accordance with WHO standard of $6.5-8.5[11,9]$. This $\mathrm{pH}$ range is close to neutrality and would allow the growth of most bacterial species. In the studies of Kulthana et al., 2013, bottled drinking water had $\mathrm{pH}$ between 6.9 and 7.5. Water derived from home water filters had an approximate $\mathrm{pH}$ of 7.5 [13].

Our present study revealed that all the water samples fell within the temperature range of $22-23.4^{\circ} \mathrm{C}$ which is in accordance with values obtained by [6].

The temperature range of $22-28^{\circ} \mathrm{C}$ could be said to be suitable for the growth of heterotrophic bacterial species when present in the sample.

The total dissolved solids of the sachet and bottled water samples fell within the range of $0.18-1.60 \mathrm{mg} / \mathrm{ml}$ whereas that of the borehole water samples fell within the range of 31.3-35.4 $\mathrm{mg} / \mathrm{ml}$ (Table 2) which were all within the standards $(500 \mathrm{mg} / \mathrm{ml})[1,11]$. The total soluble solid (TSS) was not detected in the sachet and bottled water samples indicating that the filtration processes for these treated water samples were properly and adequately done in all the production centres (REFS).

Regarding to the faecal coliform counts for the whole samples: Madonna Mercy, St. Matthias, Smart Cottage and Goodness lodge are unfit for drinking without processing. Standards of WHO and United States Environmental Protection Agency for faecal coliform in drinking water is zero fecal coliform per $100 \mathrm{ml}$. Therefore all the drinking water sampled from Uli were unfit for human consumption. This could be responsible for the incessant gastroenteritis, staphylococcal toxic shock syndrome, dysentery and klebsiella pneumonia infections in the area of study. Studies of Kifayatulla and Ruoyu (2018) also observed prevalence of $\mathrm{k}$ waterborne diseases including hepattis, diarrhea, typhoid fever, jaundice, cholera and skin diseases [14] (see table 5). This study suggests that all the borehole water from various sources used by the inhabitants of Uli and environs should be treated before drinking.

The presence of high faecal coliform count in sample 1, 2, 4 and 5 could be attributed to the proximity of the borehole to a pit latrine at a distance less than the $30 \mathrm{~m}$ (Tables 4 and 6). This does not conform to WHO recommendation. In addition, there is general unhygienic environment surrounding the boreholes. It could also be that the pipes used for water distribution were rusty thus allowing seepage of microbial contaminants into the borehole. There is need to increase awareness of the community towards the dangers associated with the use of contaminated water and the dangers in constructing pit latrines and septic tanks near water sources. The use of rust-free polyvinyl chloride (PVC) pipes for water distribution, and treatment of water before use for drinking and cooking should be emphasized.

\section{Conclusion}

Based on the bacteriological equality of assessed water samples from different locations in Uli, Ihiala Local Government, Anambra State, the study has attempted to examine the public health implication of packaged water products in Uli. Most packaged water apparently is of good quality, but some are contaminated. It should therefore, not be automatically assumed that packaged water in sachets and bottles, borehole is safe. The detection of E. coli. Klebsiella sp. And Staphylococcus sp. In some water sample is an evident that much are needed to be done to safeguard the health of the consumer.

Although the technologies used in the water industry may adopt little or no measure that prevent pathogen presence in the final product, the quality of the packaged water is compromised significantly as it moves from the manufacture to the consumer. Regulatory activities that promote core hygiene value (e.g. hand washing, general cleanliness of storage environment and vendor containers) and a proper handling culture could produce the derived improvements rather than a tenacious focus on end-product monitoring, which does not always give a complete picture in terms of Microbiology risk assessment. Also, an extreme shift towards implementation of the proposed ban on water sachets may not be socially desirable.

Underground water is believed to be the purest form of water because of the purification properties of the soil, however, source of contamination could be due to improper design and construction of boreholes, shallowness, and proximity to toilet, refuse dump sites, and various human activities which can serve as source of contamination. Therefore, proper borehole location is essential, good sanitation of environment and control of human activities that affect quality of drinking water. Water quality should be controlled in order to minimize acute problem of water related diseases. Domestic treatment of borehole water is also an essential means of improving water quality and regular cleaning of water reservoirs with appropriate cleaning reagents. Constant monitoring of water quality stands as a good mean of detecting earlier the deviation of drinking water from the standard.

Thus, while seeking to protect public health in developing world, there is need for regulating and agencies to maintain a balanced position that currently improves social welfare and access to drinking water.

\section{References}

[1] Akpoveta, O. V, Okoh, B E, and Osakwe S. A. (2011). Quality Assessment of Borehole Water used in the Vicinities of Benin, Edo State and Agbor, Delta State of Nigeria. Current Research in Chemistry 3: 62-69.

[2] Banu N, and Menakuru H (2010). Enumeration of Microbial Contamination in School Water. A Public Health Challenge. Health 2 (6): 582-588. 
[3] Edet A, Nganje T N, Ukpong A J, and Ekwere A S (2011). Ground water chemistry and quality of Nigeria: A Status Review. African Journal of Environmental Science and Technology 5: 1152-1169.

[4] Ezomo F O, Biose O, and Ajieh MU (2013). Evaluation of Ground water in Uromi, Edo State, Nigeria. International Journal of Scientific and Engineering Research 4: 3-4.

[5] Kupwade R V (2013). Pre and Post Monsoon Monitoring of Ground Water Quality in Region near Kupwad MIDC, Sangli, Maharashtra. International Journal of Chemical Technology Research 5: 2291-2294.

[6] Mgbemena N M, Obodo GA, Okonkwo N A, and Onwukeme BI (2014). Physicochemical Assessment of Borehole Waters in Ovim, Isiukwuato LGA, Abia State, Nigeria. Journal of Applied Chemistry 7: 31-33.

[7] Mustafa, A. I., Ibrahim, A. A., Haruna, Y. I., and Abubakar, S. (2013). Physicochemical and bacteriological analyses of drinking water from wash borehole in Maiduguri Metropolis, Boron State, Nigeria. African Journal of Food Science 7 (1): 9-13.

[8] Nwankwoala HO, Marshal HI, and Oborie E. (2013). Characterizations and Quantitative Indicators of Ground water Quality in Okirika, Rivers State, Nigeria. International Journal of Science Inventions Today 2: 319-334.
[9] Okeola OG, and Salami A W (2014). Ground water Resources in the Nigeria's Quest for United Nation's Millennium Development Goals (MDGs) and beyond. Journal of Sustainable Development in Africa 16: 57-71.

[10] Tripathi B, Pandey R, Raghuvanshi D, Singh H, and Pandey V, (2014). Studies on the Physico-chemical Parameters and Correlation Coefficients of the River Ganga at Holy Place, Shringverpur Allahabad. Journal of Environmental Science, Toxicology and Food Technology 8: 29-36.

[11] WHO (2013). International Standards for Drinking Water $\left(8^{\text {th }}\right.$ ed.) Geneva, pp. 36-38.

[12] Willey, J. M., Sherwood, L. M. and Woolverton, C. J. (2008). Prescott, Harley and Klein's Microbiology, $7^{\text {th }}$ edition, McGraw-Hill Company Inc., New York, Pp. 500-1060.

[13] Kulthanan, K., Piyavadee, N. and Supenya, V, (2019). The pH of water from various sources; an overview for recommendation for patients with atopic dermatitis Asian Pacific Allergy 3 (3): 155.

[14] Kifayatulla, K. and Ruoyu, L. (2019) Prevalent fecal contamination in drinking water sources and potential health risk in Swat Pakistan, Journal of Environmental Sciences 72: $1-2$. 